\title{
Properties of Winged Bean (Psophocarpus tetragonolobus) Protein in Comparison with Soybean (Glycine max) and Common Bean (Phaseolus vulgaris) Protein
}

\author{
Sonoe OCHIAI YANAGI \\ National Food Research Institute, Ministry of Agriculture, \\ Forestry and Fisheries, Kannondai, Yatabe-machi, \\ Tsukuba-gun, Ibaraki 305, Japan
}

Received February 28, 1983

\begin{abstract}
Conditions were defined which extract more than 90\% of winged bean (Psophocarpus tetragonolobus) seed proteins. Sedimentation profiles of whole seed extract from winged bean, soybean, and common bean (variety "Kintokimame") at various $\mathrm{pHs}$ and ionic strengths were compared, because winged bean and soybean are resemble each other closely in their protein- and lipid-rich nature, and winged bean and common bean (Phaseolus vulgaris) are thought to be of nearly related families. However, a clear dissimilarity of their " 6 to $7 \mathrm{~S}$ " component(s), one of the main storage proteins in the three beans, was represented. Two main peaks of winged bean protein by Sepharose 6B chromatography were shown to correspond to the "6.5S" and " $2.5 \mathrm{~S}$ " components. Extrapolated $s_{20, \mathrm{w}}$ or $s_{20, \mathrm{w}}^{0}$ of the "6.5S" component seemed to have no practical meaning because the actual structure of the " $6.5 \mathrm{~S}$ " protein distilled water or very low ionic concentrations were altered discontinuously from the usual patterns. Further purification of the " $6.5 \mathrm{~S}$ " component(s) could be carried out by rechromatography on Sepharose 6B or DEAE Sepharose, eliminating minor components. However, the electrophoretic or ultracentrifugal patterns showed the occurrence of small amounts of aggregation simultaneously. The structure of the " $6.5 \mathrm{~S}$ " component was preserved for several months by freezing.
\end{abstract}

A few reports on basic properties of winged bean (Psophocarpus tetragonolobus) seed protein have been published in the recent studies on various aspects of winged beans. Gillespie and Blagrove reported the isolation and properties of winged bean seed protein extracted with an acidic buffer (acetate chloride $\mathrm{pH} 4.5$ buffer) and they mentioned that the major proteins had sedimentation coefficients of $2 S$ and $6 \mathrm{~S} .{ }^{1)}$ Sathe and Salunkhe studied subunits' molecular weights of winged bean protein extracted with water. ${ }^{2)}$

One of the reasons why winged bean is considered to be noteworthy is the abundance of lipid and protein content which, as has become well known recently, is almost equal to that of soybeans. From another point of view, winged bean is regarded as being in a family closely related to that of common beans
(Phaseolus vulgaris) by plant classification. Therefore, winged bean protein was compared with soybean and common bean protein, using the same method of extraction, in this paper.

In another presentation 3 ) "6.5S" component was confirmed to be the general storage protein in many selections of winged bean seeds. The component(s) of " $6.5 \mathrm{~S}$," therefore, were fractionated and their properties were investigated in this paper.

\section{MATERIALS AND METHODS}

Winged bean lines were Nigeria Tpt 2 and Indonesia 909, harvested at the Okinawa Branch of the Tropical Agriculture Research Center, Ministry of Agriculture, Forestry and Fisheries. The soybean variety was Norin No. 2, and the common bean was Taisho Kintokimame.

The methods cited by Gomori ${ }^{4)}$ was mainly followed in preparing buffers. Thirty $\mathrm{mm}$ phosphate buffer, $\mathrm{pH} 7.5$,

Abbreviations: DTT, dithiothreitol, SDS, sodium dodecyl sulfate, PAGE, polyacrylamide gel electrophoresis. 
containing $0.4 \mathrm{M} \mathrm{NaCl}$ and $0.5 \mathrm{~mm}$ dithiothreitol (DTT) was called the standard buffer. Nitrogen content was determined by the micro-Kjeldahl method. ${ }^{5}$ Protein was measured by the method of Lowry6) and by ultraviolet absorption $^{7)}$ or calculated by multiplying the nitrogen value by 6.25 . Whole seed extract was prepared as mentioned in another of our papers. ${ }^{3)}$

Ultracentrifugal analyses were performed with a Hitachi 282 using a schlieren optical system and a UV absorption system at $20^{\circ} \mathrm{C}$.

Sepharose $6 \mathrm{~B}$ chromatography was carried out with a $1.6 \times 100 \mathrm{~cm}$ or $2.6 \times 100 \mathrm{~cm}$ column equilibrated with the standard buffer. Two $\mathrm{ml}$ or $5 \mathrm{ml}$ of dialyzed sample, $\mathrm{OD}_{280}=30$ to 60 for the 1 st chromatography and $\mathrm{OD}_{280} \fallingdotseq 10$ for the 2 nd chromatography, was charged and eluted with the standard buffer and fractionated to 2 to
$6 \mathrm{ml}$. Sample fractions from the Sepharose $6 \mathrm{~B}$ column was dialyzed against $30 \mathrm{~mm}$ Tris- $\mathrm{HCl}$ buffer, $\mathrm{pH} 7.5$, containing $0.1 \mathrm{M} \mathrm{NaCl}$ and $0.5 \mathrm{~mm}$ DTT and loaded onto a DEAE Sepharose column $(0.7 \times 14 \mathrm{~cm})$ previously equilibrated with the same buffer. The column was eluted with the same buffer containing $0.1 \mathrm{M} \mathrm{NaCl}$ to $0.5 \mathrm{M} \mathrm{NaCl}$, stepwise or as a gradient.

Polyacrylamide gel electrophoresis (PAGE) was performed essentially by the $\mathrm{pH} 8.2$ system of Davis ${ }^{8)}$ applied to a slab gel.

\section{RESULTS}

The effects of $\mathrm{pH}$ and ionic strength on extracting winged bean protein are summa-

TABle I. EFfect of pH and Ionic Strength on Extraction of Winged Bean Protein

\begin{tabular}{|c|c|c|c|c|c|c|c|}
\hline \multirow[b]{2}{*}{ Buffer $^{a}$} & \multirow[b]{2}{*}{$\mathrm{pH}$} & \multirow[b]{2}{*}{$\mu^{a}$} & \multicolumn{2}{|c|}{$\mathrm{OD}_{280}$} & \multirow{2}{*}{$\begin{array}{l}\text { Solubilized } \\
\text { N-substance/Total } \\
\text { N-substance }{ }^{b}- \\
(\%)\end{array}$} & \multicolumn{2}{|c|}{$\begin{array}{l}\text { Solubilized protein } \\
\mathrm{mg} / \mathrm{g} \mathrm{sample}^{c}\end{array}$} \\
\hline & & & $\begin{array}{l}\text { Crude } \\
\text { extract }\end{array}$ & Dialyzed & & $A^{b}$ & $\mathrm{~B}^{d}$ \\
\hline \multirow[t]{6}{*}{ Acetate } & 4.5 & 0.1 & 39 & 16 & & & \\
\hline & & 0.3 & 44 & 19 & & & \\
\hline & & 0.5 & 50 & 23 & & & \\
\hline & 5.2 & 0.1 & 40 & 18 & & & \\
\hline & & 0.3 & 42 & 20 & 72 & 234 & 226 \\
\hline & & 0.5 & 47 & 24 & 75 & 238 & 259 \\
\hline \multirow[t]{9}{*}{ Phosphate } & 6.0 & 0.1 & 55 & 20 & & & \\
\hline & & 0.3 & 57 & 21 & & & \\
\hline & & 0.5 & 56 & 20 & & & \\
\hline & 7.0 & 0.1 & 62 & 22 & & & \\
\hline & & 0.3 & 61 & 21 & & & \\
\hline & & 0.5 & 59 & 23 & & & \\
\hline & 7.5 & 0.1 & 64 & 29 & & & \\
\hline & & 0.3 & 65 & 30 & 93 & 322 & 311 \\
\hline & & 0.5 & 67 & 29 & & & \\
\hline \multirow[t]{9}{*}{ Tris- $\mathrm{HCl}$} & 7.0 & 0.1 & 50 & 18 & & & \\
\hline & & 0.3 & 59 & 23 & & & \\
\hline & & 0.5 & 63 & 27 & & & \\
\hline & 8.0 & 0.1 & 76 & 30 & 90 & 311 & 302 \\
\hline & & 0.3 & 73 & 30 & 93 & 323 & 314 \\
\hline & & 0.5 & 75 & 31 & & & \\
\hline & 9.0 & 0.1 & 32 & 13 & & & \\
\hline & & 0.3 & 34 & 13 & & & \\
\hline & & 0.5 & 31 & 15 & & & \\
\hline \multirow[t]{3}{*}{ Borax-NaOH } & 10.0 & 0.1 & 53 & 23 & & & \\
\hline & & 0.3 & 50 & 25 & & & \\
\hline & & 0.5 & 53 & 27 & & & \\
\hline
\end{tabular}

a Buffer concentration was $30 \mathrm{~mm}$, and ionic strength $(\mu \mathrm{m})$ was adjusted with $\mathrm{NaCl}$.

$b$ Measured by the Kjeldahl method. ${ }^{5)}$

c Milligrams protein for dry weight sample. Measured by the Kjeldahl method. ${ }^{\text {) }}$

d Measured by the Lowry et al.'s method. ${ }^{6)}$ 
rized in Table I. Tris- $\mathrm{HCl}$ buffer, $\mathrm{pH} 8.0$, was the best for extracting $\mathrm{OD}_{280}$ absorbing substances. Phosphate buffer, $\mathrm{pH} 7.5$, had the same effect in extracting undialyzable high molecular weight $\mathrm{OD}_{280}$ absorbing substances as Tris- $\mathrm{HCl}$ buffer, $\mathrm{pH}$ 8.0. Extracted nitrogenous substances to total $\mathrm{N}$-substances measured by the Kjeldahl method were more than $90 \%$ for Tris- $\mathrm{HCl}(\mathrm{pH} 8.0)$ and phosphate $(\mathrm{pH}$ $7.5)$ buffers. With acetate buffer, less than $75 \%$ of total nitrogen could be taken out even if the constituents of the buffer were the same as Gillespie and Blagrove's. ${ }^{1)}$ Not only $\mathrm{pH}$ but also the kind of buffer was significant, because a large amount of precipitation was observed with citrate buffer extraction in a wide acidic range of $\mathrm{pH}$ ( $\mathrm{pH} 3.0$ to 6.0 , data not shown). The amount of solubilized protein was measured for dialyzed whole seed extract by the Kjeldahl and Lowry methods. Results of the two methods generally agreed for the most of the $\mathrm{pH}$ range and ionic strengths examined. As the total protein content of this winged bean was $34.8 \%$, ${ }^{3)}$ these results were also very con- sistent with the percentages of solubilized-N/ total-N. An ionic strength of 0.1 was not as effective in extracting $\mathrm{OD}_{280}$ absorbing substances for both crude dialyzed extracts as ionic strengths of 0.3 and 0.5 through all of the $\mathrm{pH}$ range. Considering these results and comparing them with other legume protein reports,

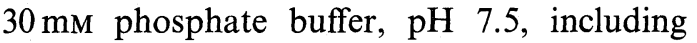
$0.4 \mathrm{M} \mathrm{NaCl}$ and $0.5 \mathrm{~mm}$ DTT was chosen for the standard buffer for extracting winged bean protein in our experiments.

Sedimentation diagrams of whole seed extracts from winged bean, soybean, and common bean at various pHs are exhibited in Fig. 1. The sedimentation profiles of winged bean proteins were fundamentally similar from a $\mathrm{pH}$ of 4.0 (data not shown) to $\mathrm{pH} 9.0$. The two main peaks were about " $6.5 \mathrm{~S}$ " and about " $2.5 \mathrm{~S}$ " at $\mathrm{pH} 7.5$ (patterns of 8 different winged bean strains were shown in another paper $^{3)}$ ), with larger $\mathrm{S}$ values at acidic $\mathrm{pHs}$ and smaller $\mathrm{S}$ values at basic pHs. Soybean proteins showed almost the same phenomena as winged bean proteins with alteration of $\mathrm{pH}$.

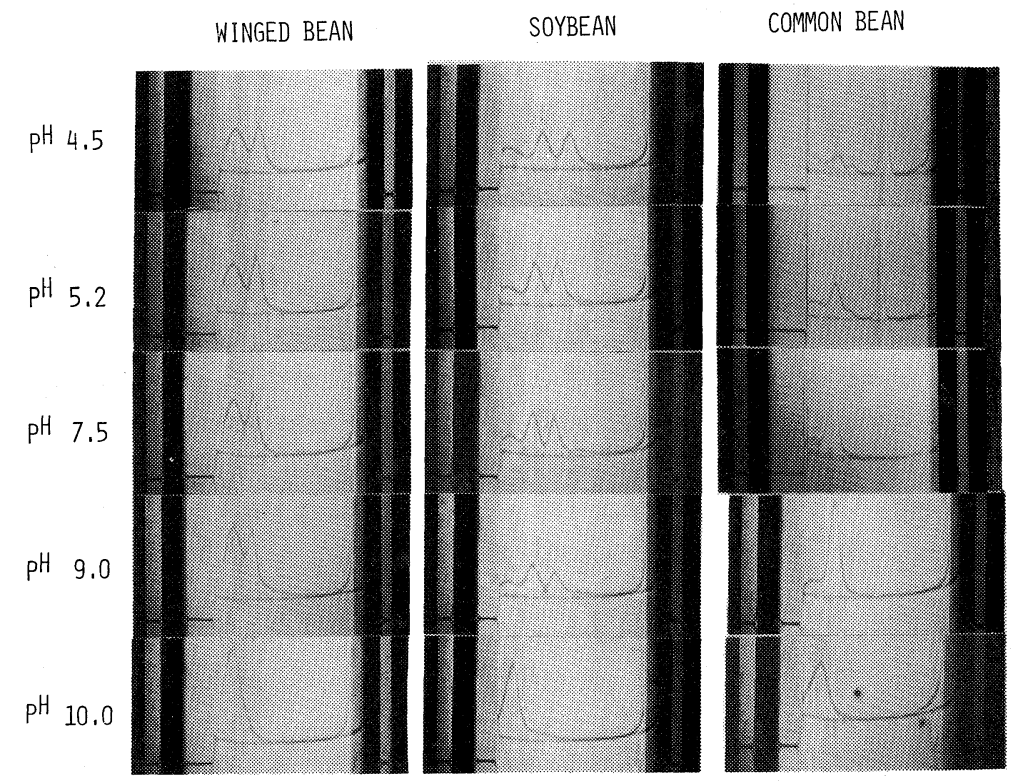

Fig. 1. Schlieren Patterns of Whole Seed Extracts from Winged Bean, Soybean, and Common Bean (Kintokimame), at Various pHs.

Whole extracts in standard buffer were dialyzed against the same buffer or acetate $\mathrm{pH} 4.5$ or 5.2 , or Tris- $\mathrm{HCl}$ $\mathrm{pH} 9.0$ or borate $\mathrm{pH} 10.0$ buffers with concentrations of $30 \mathrm{~mm}$ and containing $0.4 \mathrm{M} \mathrm{NaCl}$ and $0.5 \mathrm{~mm}$ DTT. The figures shown were at $30 \mathrm{~min}$ after reaching $55,430 \mathrm{rpm}$ at $20^{\circ} \mathrm{C}$. 


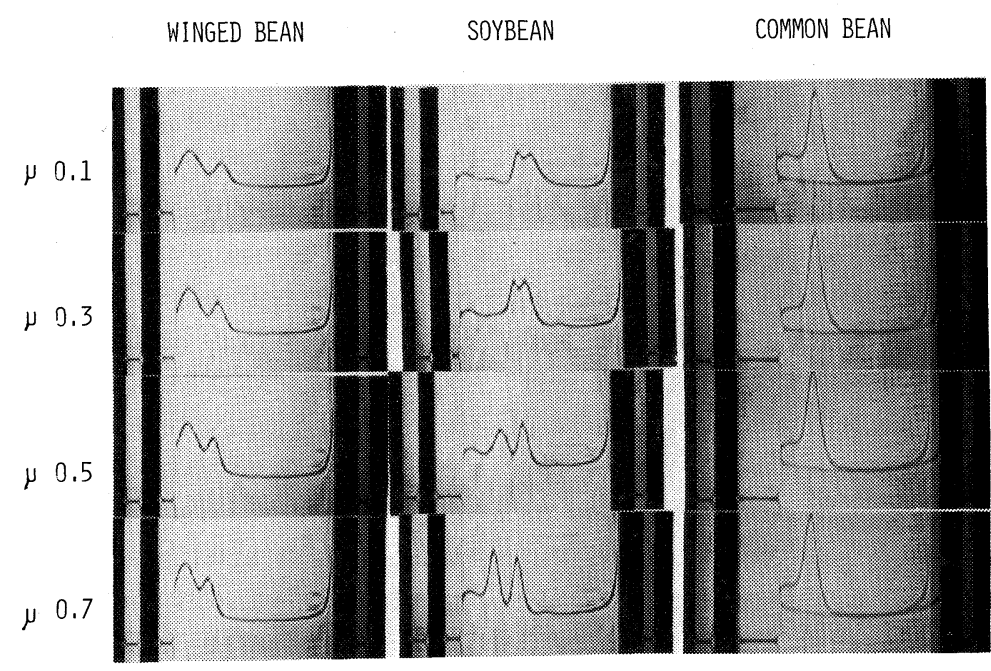

FIG. 2. Sedimentation Diagrams of Whole Seed Extracts from Winged Bean, Soybean, and Common Bean (Kintokimame) at Various Ionic Strengths.

Whole extracts in standard buffer were dialyzed against the same buffer or the same phosphate buffers with ionic strengths of $0.1,0.3$, and 0.7 . The patterns shown were at $30 \mathrm{~min}$ after reaching $55,430 \mathrm{rpm}$ at $20^{\circ} \mathrm{C}$.

The sedimentation coefficients of the main soybean protein were about " $7 \mathrm{~S}$ " and " $11 \mathrm{~S}$," and minor components of about $3 \mathrm{~S}$ and about $15 \mathrm{~S}$ were seen at $\mathrm{pH} 7.5$. But the main $7 \mathrm{~S}$ and $11 \mathrm{~S}$ peaks shifted to about $8.5 \mathrm{~S}$ and $14 \mathrm{~S}$ at $\mathrm{pH}$ 4.5 and a little smaller $\mathrm{S}$ values at $\mathrm{pH}$ 9.0. The association-dissociation phenomenon of common bean proteins for $\mathrm{pH}$ change were quite different from those observed above with winged bean and soybean. Most of the "7S" protein of common beans (Kintokimame) at neutral $\mathrm{pH}$ were shown to associate to become about $18 \mathrm{~S}$ protein at $\mathrm{pH}$ under 6.0. This phenomenon with French bean (Phaseolus vulgaris) was reported by Sun et al. ${ }^{9)}$ At $\mathrm{pH} 10.0$ all proteins of the three beans were dissociated to 2 to $4 \mathrm{~S}$ components. This dissociation was partially reversible. From these results winged bean " $6.5 \mathrm{~S}$ " protein(s) was distinctly shown to have a different physicochemical nature from most of common bean "7S" protein(s) though Psophocarpus and Phaseolus are thought to be from closely related families.

In Fig. 2 schlieren patterns of whole seed extracts from the three beans at ionic strengths of 0.1 to 0.7 are demonstrated. Proteins from winged beans and common beans did not have intensive differences with ionic change, except that the $S$ values of peaks were smaller at high ionic strengths and larger at low ionic strengths. Soybean proteins, however, showed quite different sedimentation diagrams at various ionic strengths. The well known soybean protein pattern of two clear main components, "7S" and "11S," was seen at an ionic strength of 0.5 and the separation of two peaks was clearer at an ionic strength of 0.7 , showing that the " $7 \mathrm{~S}$ " became smaller. At ionic strengths of 0.1 and 0.3 the $S$ values of the two main peaks were very close to each other. Thus the main winged bean " $6.5 \mathrm{~S}$ " protein was shown to be different from soybean "7S" protein too in physical or chemical character. At ionic strengths of lower than 0.1 , not only soybean but also winged bean and common bean protein too changed drastically in their structure. The details of these phenomena will be mentioned on another occasion.

Whole winged bean extract was fractionated with Sepharose 6B column chromatography. As shown in Fig. 3-a, the elution profile mainly consisted of three peaks: the first peak at void volume, the 2 nd and 3 rd peaks designated as A and $B$. The sedimentation pattern of each peak is shown in Fig. 3-b. The void peak contained 


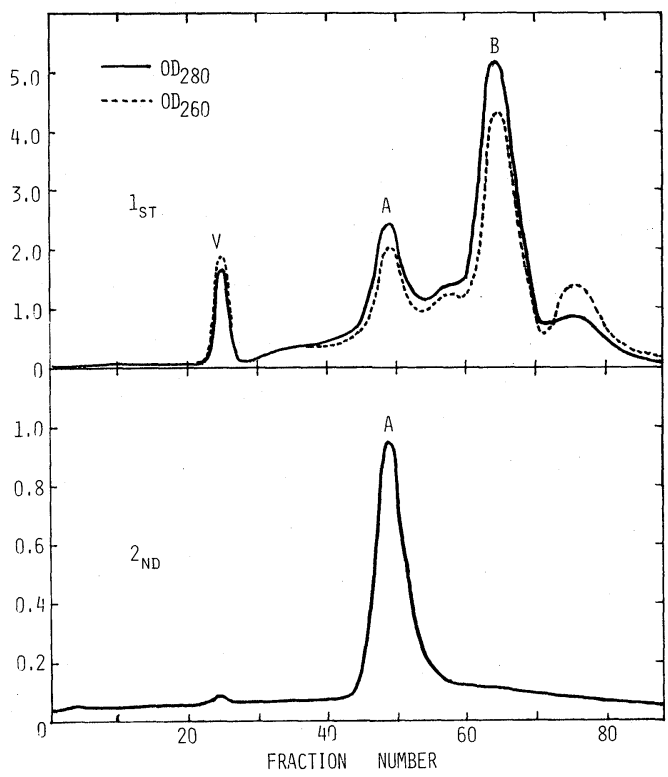

a
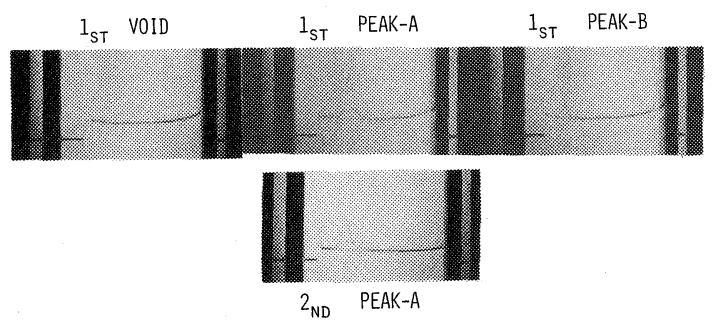

b

FIG. 3. a: Fractionation of Whole Winged Bean Proteins through Sepharose 6B Column Chromatography (Top) and Rechromatography of Peak A Fraction from the 1st Chromatography (Bottom).

The column was equilibrated and eluted with standard buffer, and the fraction volume was $6 \mathrm{ml}$.

b: Sedimentation Patterns of Fractionated Winged Bean Proteins through Sepharose 6B Chromatography.

Photographs were taken $30 \mathrm{~min}$ after reaching 55,430 rpm.

only very large molecular weight substance(s) which could not be observed under these centrifugal conditions. Peak A and peak B corresponded to the " $6.5 \mathrm{~S}$ " and " $2.5 \mathrm{~S}$ " components, respectively. As mentioned in our other report, ${ }^{3)}$ peak B was a mixture of many proteins which were different for various strains of winged beans. The main component of peak A seemed to be common to all winged beans in the results of chromatography profiles, PAGE, and sedimentation analyses. ${ }^{3)}$

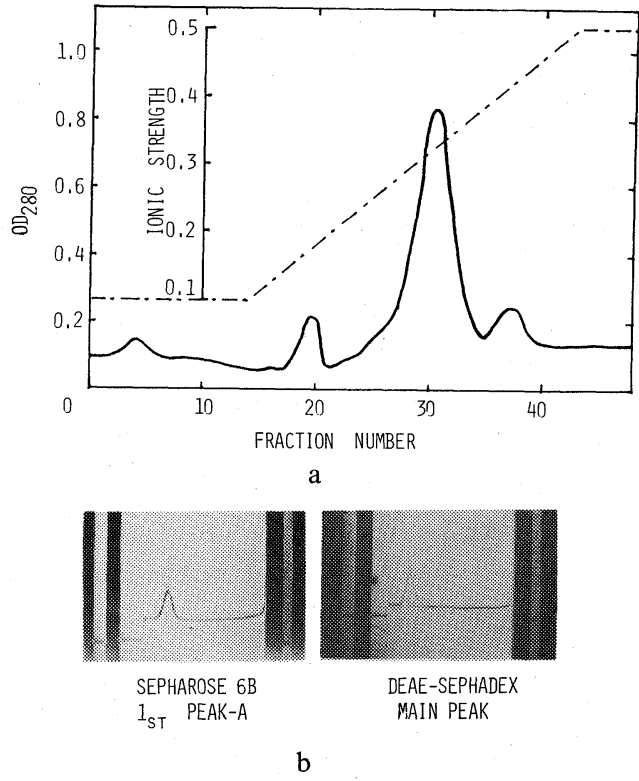

FIG. 4. a: DEAE Sepharose Chromatography of the 1st Sepharose 6B Peak A, the "6.5S" Component(s) of Winged Bean.

Pooled peak A fractions were dialyzed against $30 \mathrm{~mm}$ Tris$\mathrm{HCl}$ buffer, $\mathrm{pH} 7.5$, containing $0.1 \mathrm{M} \mathrm{NaCl}$ and $0.5 \mathrm{~mm}$ DTT and charged to the column equilibrated with the same buffer. Elution was carried out with the same buffer containing 0.1 to $0.5 \mathrm{M}$ of $\mathrm{NaCl}$ in a gradient.

b: Sedimentation Profile of the "6.5S" Component(s) of Winged Bean before and after DEAE Chromatography.

Pictures were at $30 \mathrm{~min}$ after reaching $55,430 \mathrm{rpm}$.

Therefore peak $\mathrm{A}$, the " $6.5 \mathrm{~S}$ " component(s), was assumed in this paper to be the main winged bean storage protein. As seen by the elution pattern of rechromatography and the sedimentation pattern, peak $A$, the " $6.5 \mathrm{~S}$ " component(s), was almost isolated as a chromatographically and centrifugally single peak by one passage through a Sepharose 6B gel column. Rather larger amounts of high molecular weight substances could be observed in the sedimentation profile after the 2 nd chromatography (bottom-side tailing). These high molecular component(s) might have been generated after chromatography elution.

The Sepharose 6B fraction A was chromatographed with DEAE Sephadex or DEAE Sepharose (Fig. 4-a). Both results were fundamentally the same. At $0.1 \mathrm{M} \mathrm{NaCl}$ con- 
centration, almost all the protein components were bound to the ion exchange gel. A main peak began to be eluted at $0.25 \mathrm{M} \mathrm{NaCl}$. Before and after the main peak, small peaks were separated according to the $\mathrm{NaCl}$ gradient. In spite of this purification procedure, the sedimentation profile of the DEAE Sepharose main peak was not as sharp as the 1st chromatography of Sepharose 6B peak A, and the high molecular side tailing was seen, just as after Sepharose 6B rechromatography (Fig. 3-b, Fig. 4-b). The alteration of ionic strength of the solution, an ion exchange reaction or some other unknown factor might have cause aggregation.

As seen in Fig. 5-a, DEAE Sepharose fractions, like the Sepharose 6B fractions, did not present a sharp PAGE band. Electrophoresis in high ionic strength, adding $0.4 \mathrm{M} \mathrm{NaCl}$, could not prevent the band from becoming broad (Fig. 5-b). The "6.5S" components of winged bean might have some variations of molecular size or amino acid components.

The sedimentation coefficient, $s_{20}$, of Sepharose 6B peak A of UPS-99 was analyzed at several concentrations (Fig. 6-a) and in solutions of various ionic strengths (Fig. 6-b). When the protein concentration became lower, the value of $s_{20}$ went up slightly at the ionic strength of 0.5 . Calculated $s_{20, \mathrm{w}}$ were about $0.5 \mathrm{~S}$ larger than the measured $s_{20}$ of this condition, so the extrapolated $s_{20, \mathrm{w}}^{0}$ was 6.9.
The acturally measured $s_{20}$ value came in a wide range in proportion to the ionic strength of the solution, and the measured $s_{20, w}$ in the solution of $\mathrm{OD}_{280}=3.0$ with and without DTT were 6.7 and 7.0 , but the $s_{20, w}$ extrapolated from the measured values of $\mu=0.05$ to $\mu=0.5$ was 8.1 (Fig. 6-b). Besides the actual $s_{20, w}$ in concentrated solutions higher than $\mathrm{OD}_{280}=3$ were much less than 6.7 (data not shown). The structure of the protein seemed to be changed

a

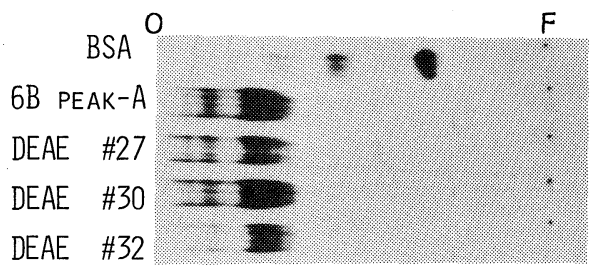

b

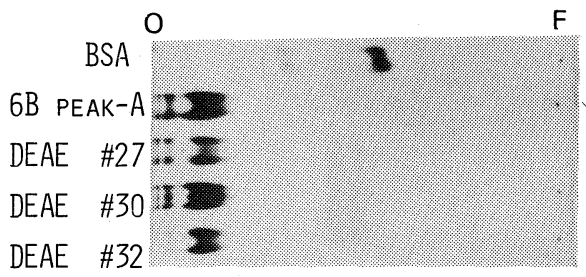

FIG. 5. Electrophoresis Pattern of the Winged Bean "6.5S" Peak before and after DEAE Chromatography.

$a$, by the ordinary PAGE method of Davis'); $b$, in high ionic concentration buffer. $\mathrm{O}$, origin; $\mathrm{F}$, front; \#27 to 32 , correspond to the fraction numbers in Fig. 4-a; BSA, bovine serum albumin.
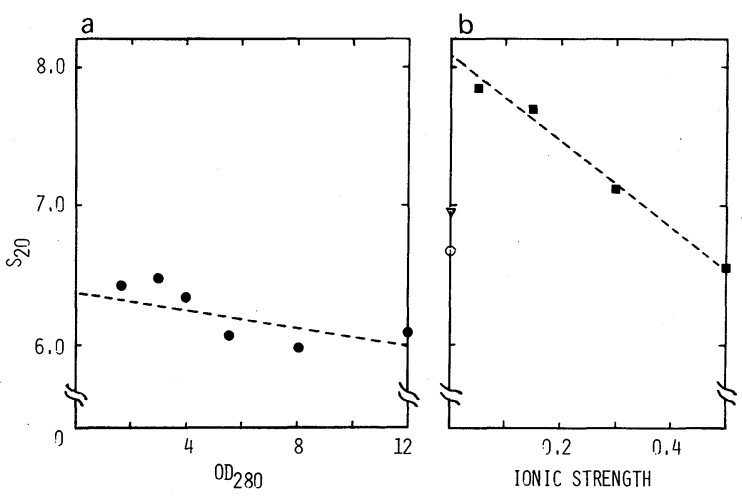

FIG. 6. Sedimentation Coefficient of the Sepharose 6B Peak A of Winged Bean Seed Proteins (UPS-99). a, with change of protein concentration. Ionic strength of the solution was 0.5 . b, with change of ionic strength of the solution. $\mathrm{OD}_{280}$ of the solution was 3.0. $\bigcirc$ and $\triangle$, measured in distilled water adjusted to $\mathrm{pH} 7.5$ with and without $0.5 \mathrm{~mm}$ DTT, respectively. 


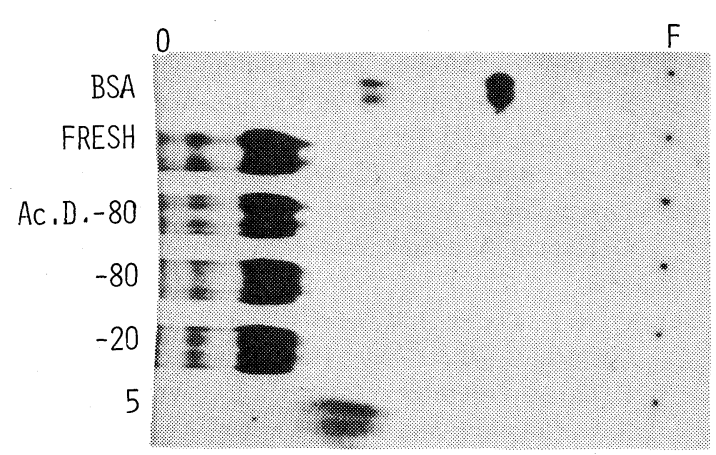

FIG. 7. Effects of Storage Conditions on the "6.5S" Protein of Winged Bean Seed.

Fresh, fresh fraction of peak A from Sepharose 6B chromatography; Ac.D. -80 , frozen with acetone dry ice and stored at $-80^{\circ} \mathrm{C} ;-80$, stored directly at $-80^{\circ} \mathrm{C}$; -20 , stored directly at $-20^{\circ} \mathrm{C} ; 5$, stored at $5^{\circ} \mathrm{C}$, for 5 months. O, origin of PAGE; $\mathrm{F}$, front of PAGE; BSA, bovine serum albumin.

considerably according to the ionic strength of the solution and the concentration of the protein. Therefore, calculation and extrapolation seemed not have practical meaning and accurate $S$ values must be mentioned with the conditions of measurement.

Freezing was a very good method for preserving the structure of the " $6.5 \mathrm{~S}$ " protein. Samples kept in the refrigerator for a long time were degraded and the original proteins were not seen at all by PAGE (Fig. 7). Keeping the sample in a $-80^{\circ} \mathrm{C}$ freezer after acetone dry ice freezing, or keeping in a $-80^{\circ} \mathrm{C}$ freezer directly, or keeping in a $-20^{\circ} \mathrm{C}$ freezer directly for five months gave electrophoretically and ultracentrifugally the same protein profile as the freshly prepared fraction.

\section{DISCUSSION}

The profiles of winged bean proteins described in this paper could be thought to reflect almost the total aspect of storage protein in seeds, because the standard buffer use here could extract more than $90 \%$ of the total $\mathrm{N}$-substances in the seeds, as seen in Table I.

The main winged bean proteins were separated into two components at various $\mathrm{pHs}$ and ionic strengths, and higher molecular weight proteins than the " $6.5 \mathrm{~S}$ " component were not observed, unlike with soybeans, though both beans were so prominent for high protein contents (more than 30\%). The protein content of common beans was much less than winged beans (around 25\%) and the ratio of the " $6.5 \mathrm{~S}$ " component(s) to " 2 to $3 \mathrm{~S}$ " components was distinctly higher than that of winged bean. So the storage protein content of beans and the content of larger molecular protein was shown to have no relationship. The " $18 \mathrm{~S}$ " component, which was the major peak of the common proteins in acidic conditions, was not observed at all with winged beans including the various stages of bean development. ${ }^{10)}$

Though the ultracentrifugal pattern of the "6.5S" component of winged beans after only one passage of Sepharose 6B chromatography was an almost symmetrical single peak and only traces of tailing components before and after the peak were seen, the main PAGE band was broad, besides the existence of a few minor bands. The minor components could not be eliminated completely by DEAE Sepharose chromatography (Fig. 5) nor by CM Sepharose chromatography (data not shown). High molecular weight aggregates of the " $6.5 \mathrm{~S}$ " components seemed to be present in rather larger amounts after rechromatography on Sepharose 6B or DEAE Sepharose. Therefore, to know the fundamental nature of the " $6.5 \mathrm{~S}$ " component, analyses of sedimentation coefficient were performed using the peak A fraction from the 1st Sepharose 6B chromatography.

Seeing that the results of Fig. 6 and the sedimentation pattern of whole seed extract in higher protein concentrations and in very low ionic strengths was quite different from the patterns shown in Figs. 1 and 2 (data not shown), the actual $s_{20 \text {,w }}$ or $s_{20, w}^{0}$ of this component was difficult to determine simply, and to decide those values by extrapolation with measured $S$ values seemed to have no practical meaning. The majority of the seed storage protein may have a very small molecular weight distribution and variation of constituent amino acids, seeing the results of Fig. 5- 
$a$ and $-b$. The details of these heterogenieties have to be studied in relationship to varieties and maturities, and have been left to be subjects of a future paper.

Acknowledgments. Author wishes to give cordial thanks to Mr. H. Takada and Mr. J. Abe, of the Okinawa branch of the Tropical Agriculture Research Center, and Dr. S. Uemoto, Kyushu University, for supplying the winged bean seeds.

\section{REFERENCES}

1) J. M. Gillespie and R. J. Blagrove, Aust. J. Plant Physiol., 5, 357 (1978).

2) S. K. Sathe and D. K. Salunkhe, J. Food Sci., 46, 1389 (1981).

3) S. O. Yanagi, N. Yoshida and K. Saio, Agric. Biol.
Chem., 47, 2267 (1983)

4) G. Gomori, "Method in Enzymology," Vol. I, ed. by S. P. Colowick and N. O. Kaplan, Academic Press Inc., New York, 1955, p. 138.

5) R. H. Burris and P. W. Wilson, "Methods in Enzymology," Vol. IV, ed. by S. P. Colowick and N. O. Kaplan, Academic Press Inc., New York, 1957, p. 356.

6) O. H. Lowry, N. J. Rosebrough, A. L. Farr and R. J. Randall, J. Biol. Chem., 193, 265 (1951).

7) E. Layne, "Method in Enzymology," Vol. III, ed. by S. P. Colowick and N. O. Kaplan, Academic Press Inc., New York, 1957, p. 447.

8) B. J. Davis, Ann. N. Y. Acad. Sci., 121, 404 (1964).

9) S. M. Sun, R. C. McLeester, F. A. Bliss and T. C. Hall, J. Biol. Chem., 249, 2118 (1974).

10) S. O. Yanagi, M. Kato and S. Uemoto, Agric. Biol. Chem., 47, 2387 (1983). 